\title{
Fusarium lini Potential for the Biotransformation of Norandrostenedione and Evaluation of Urease and Chymotrypsin Properties of the Transformed Products
}

\author{
Simeon Pierre Chegaing Fodouop ${ }^{1,2 *}$, Alex Doris Kengni Mboussaah ${ }^{2,3}$, \\ Didiane Yemele Mefokou1, Alain Bertrand Fowa', Mahwish Siddiqui2,5, \\ Gabriel T. Kamsu4, Donatien Gatsing4, Muhammad Iqbal Choudhary 2,5
}

\begin{abstract}
${ }^{1}$ Research Unit of Metabolic and Infectious Diseases, Department of Biomedical Sciences, Faculty of Science, University of Ngaoundéré, Ngaoundéré, Cameroon

${ }^{2}$ H.E.J. Research Institute of Chemistry, International Center for Chemical and Biological Sciences, University of Karachi, Karachi, Pakistan

${ }^{3}$ Research Unit of Applied Chemistry, Department of Chemistry, Faculty of Science, University of Dschang, Dschang, Cameroon ${ }^{4}$ Research Unit of Microbiology and Antimicrobial Substances, Department of Biochemistry, Faculty of Science, University of Dschang, Dschang, Cameroon

${ }^{5}$ International Center for Chemical and Biological Sciences, University of Karachi, Karachi, Pakistan

Email: *saafodouop@yahoo.fr
\end{abstract}

How to cite this paper: Fodouop, S.P.C., Mboussaah, A.D.K., Mefokou, D.Y., Fowa, A.B., Siddiqui, M., Kamsu, G.T., Gatsing, D. and Choudhary, M.I. (2021) Fusarium lini Potential for the Biotransformation of Norandrostenedione and Evaluation of Urease and Chymotrypsin Properties of the Transformed Products. Advances in Biological Chemistry, 11, 65-77.

https://doi.org/10.4236/abc.2021.112006

Received: November 1, 2020

Accepted: April 19, 2021

Published: April 22, 2021

Copyright $\odot 2021$ by author(s) and Scientific Research Publishing Inc. This work is licensed under the Creative Commons Attribution International License (CC BY 4.0).

http://creativecommons.org/licenses/by/4.0/ (c) (i) Open Access

\section{Abstract}

Several androgenic steroids have been biotransformed by fungi into metabolites with numerous biological properties. Incubation of norandrostenedione (1) with Fusarium lini NRRL 2204 was carried out for the first time, yielding two new metabolites, 3,7 $\beta$-dihydroxy-19-norandrost-1,3,5-trien-17-one (3) and $6 \alpha, 10 \beta, 17 \beta$-trihydroxy-19-nor-4-androsten-3-one (4), along with three known compounds, 3-hydroxy-19-norandrost-1,3,5-trien-17-one (2), $10 \beta$, $17 \beta$-dihydroxy-19-nor-4-androsten-3-one (5) and $10 \beta$-hydroxy-19-nor-4androsten-3,17-dione (6). Their structures were elucidated by extensive spectroscopic analyses, including 1D-, 2D-NMR, and HR-MS experiments. Substrate 1 and its derivatives 2-6 were evaluated in vitro for their urease and chymotrypsin inhibitory properties. Compounds 2 and 3 were found to have strong urease activity with $\mathrm{IC}_{50}=23.7 \pm 0.17$ and $10.2 \pm 0.28 \mu \mathrm{m}$, respectively, as compared to the standard drug thiourea $\left(\mathrm{IC}_{50}=21.6 \pm 0.12 \mu \mathrm{m}\right)$. Compounds 4, 5 and 6 showed good chymotrypsin activity with $\mathrm{IC}_{50}$ values of $6.4 \pm 0.19,15.6 \pm 0.46$ and $18.4 \pm 0.65 \mu \mathrm{m}$, respectively, as compared to standard chymostatin with $\mathrm{IC}_{50}=5.7 \pm 0.14 \mu \mathrm{m}$. These transformed metabolites 
may form the basis for the future development of new drugs against ulcer, in-

flammation, bacterial and viral diseases.

\section{Keywords}

Chymotrypsin Inhibition, Norandrostenedione, Fusarium lini,

Urease Inhibition

\section{Introduction}

Increased microbial resistance to pharmaceuticals has prompted researchers to move towards the use of naturally occurring antimicrobial substances. Despite the effectiveness of natural substances in the treatment of diseases, the limited amount of natural resources forces researchers to seek alternative sources to obtain new active compounds. Several studies have shown that bioactive molecules can be biotransformed into other compounds with new biological properties [1] [2] [3]. Biotransformations are organic reactions using biological catalysts. They are used in many different conditions such as free enzymes or whole cells. Biocatalysts can be used for regio- and stereo-selective reactions, or to introduce chirality in a way that would be very difficult, if not impossible, with classical chemical syntheses [4]. A number of studies have shown that several androgenic steroids have been biotransformed by fungi into metabolites with numerous biological properties [5] [6] [7]. Because of their stereochemistry (presence of many asymmetric centres and inert hydrocarbon skeletons), the hydroxylation, oxidation and epoxidation of steroids are difficult tasks for organic chemists. However, these reactions are readily possible by appropriate biotransformations [5].

Norandrostenedione is an anabolic steroid taken as dietary supplements by athletes who want to build up muscle mass and aggression. 19-norandrostenedione refers to two steroid isomers that were once marketed as dietary supplements and mainly used by bodybuilders. They can also be taken by people who are HIV-positive and others with muscle atrophy caused by illness. When taken either orally or by injection, norandrostenedione is metabolised in the body to 19-norandrosterone [8].

Ureolytic activity plays a key role in the pathogenesis of bacteria such as Clostridium perfringens, Helicobacter pylori, Klebsiella pneumoniae, Proteus mirabilis, Salmonella spp., Staphylococcus saprophyticus, Ureoplasma urealyticum, Yersinia enterocolitica [9] [10], and fungi such as Cryptococcus neoformans and Coccidioides posadasii [11]. Ammonia produced during the hydrolysis of urea by ureases is toxic for human cells and may help the disease to spread into a systemic infection. Bacterial ureases are thus involved in the pathogenesis of many diseases. Urease is also an immunogenic protein and is recognized by antibodies present in human sera. The presence of such antibodies is connected with pro- 
gress of several long-lasting diseases, like rheumatoid arthritis, atherosclerosis or urinary tract infections. Taking into consideration that the human genome does not contain urease-encoding genes [11], the inhibition of urease activity can be considered an effective means of treating certain microbial infections. On the other hand, proteolytic enzymes such as chymotrypsin have been used to facilitate tissue repair since ancient times. It provides better resolution of inflammatory symptoms and promotes faster recovery of acute tissue injury [12] [13].

In continuity of our work developing new bioactive substances, we reported in our previous biotransformation investigation of norandrostenedione by Cunninghamella blakesleeana ATCC 8688A, the hemisynthesis and structure elucidation of four steroids, including one new, $6 \alpha, 10 \beta$-dihydroxy-19-nor-4-androsten3 -one, along with three know compounds: $10 \beta$-hydroxy-19-nor-4-androsten3,17-dione, $6 \beta, 10 \beta, 17 \beta$-trihydroxy-19-nor-4-androsten-3-one and $10 \beta, 17 \beta$ - dihydroxy-19-nor-4-androsten-3-one [14]. The present study is aimed to follow up the biotransformation of norandrostenedione by Fusarium lini and to evaluate the urease and chymotrypsin inhibition properties of the transformed products.

\section{Results and Discussion}

Six metabolites 2-6, including two new ( 3 and 4 ) and three known ones $(2,5$ and 6) were isolated from the fermentation of norandrostenedione (1) $\left(\mathrm{C}_{18} \mathrm{H}_{24} \mathrm{O}_{2}\right.$, $m / z=272.1$ ), with Fusarium lini NRRL 2204 (Figure 1). This transformation has not been previously reported in the literature. The chemical structures of three known steroids 2, 5 and 6 , which are here obtained for the first time by biotransformation from Fusarium lini, were identified by comparison of their physical and spectral data with previously reported data as 3-hydroxy-19-norandrost1,3,5-trien-17-one (2) [15], 10 $\beta, 17 \beta$-dihydroxy-19-nor-4-androsten-3-one (5) [5] [14] [16] and 10 $\beta$-hydroxy-19-nor-4-androsten-3,17-dione (6) [5] [14]. Compounds 5 and $\mathbf{6}$ were previously synthesized by the biotransformation of 1 with Cunninghamella blakesleeana ATCC 8688A [14], while compound 2 was reported from biotransformation of estradiol valerate by Fusarium lini NRRL 2204 [15].

Compound 3 was obtained as a white solid, m.p. $=152^{\circ} \mathrm{C}-155^{\circ} \mathrm{C}$, soluble in $\mathrm{CDCl}_{3}$. HR-EI-MS showed the quasi-molecular ion peak $[\mathrm{M}]^{+}$at $\mathrm{m} / \mathrm{z}=286.1563$, indicating the formula $\mathrm{C}_{18} \mathrm{H}_{22} \mathrm{O}_{3}$ (calcd. $\mathrm{m} / z=286.1567$ ), consistent with eight degrees of unsaturation, which is consistent with dehydrogenation (aromatization) of the A-ring, followed by hydroxylation of compound 1. Absorption bands in the IR spectrum at 3405, 1720 and $1657 \mathrm{~cm}^{-1}$ indicated the presence of hydroxyl $(\mathrm{OH})$, carbonyl $(\mathrm{C}=\mathrm{O})$ and aromatic groups $(\mathrm{C}=\mathrm{C})$, respectively. The ultraviolet spectrum showed absorption maxima at $\lambda_{\max } 230$ and $243 \mathrm{~nm}$ which indicate the presence of a benzene ring in the molecule. In the ${ }^{1} \mathrm{H}$ NMR spectrum (Table 1), three aromatic protons resonate as an $\mathrm{ABX}$ system at $\delta_{\mathrm{H}}=7.18(1 \mathrm{H}, \mathrm{d}$, 

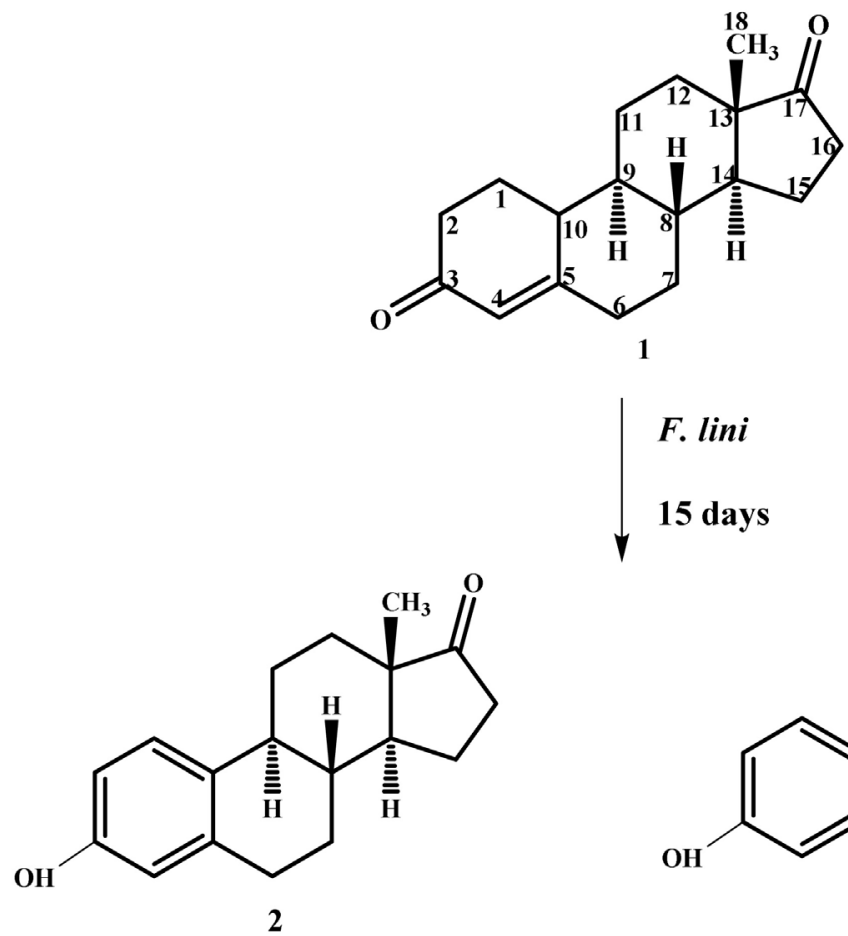

\section{F. lini}

15 days

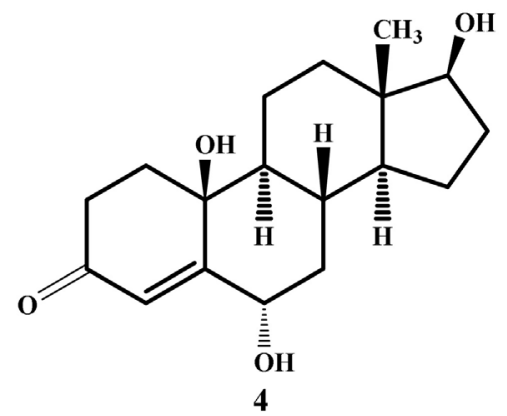

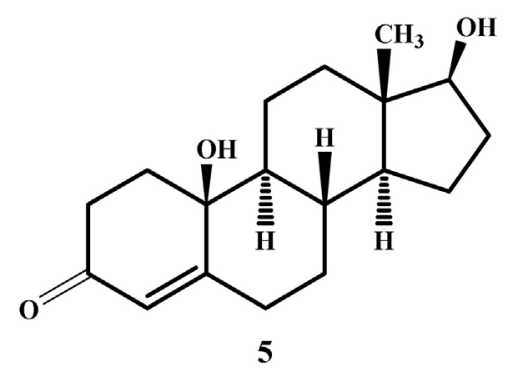<smiles>C[C@]12CC[C@@H]3[C@@H](CCC4=CC(=O)CC[C@]43O)[C@@H]1CCC2=O</smiles>

Figure 1. Biotransformation of norandrostenedione (1) with Fusarium lini.

$J=8.8 \mathrm{~Hz}), 6.65(1 \mathrm{H}, \mathrm{dd}, J=2.5-8.8 \mathrm{~Hz})$ and $6.56 \mathrm{ppm}(1 \mathrm{H}, \mathrm{d}, J=2.5 \mathrm{~Hz})$, which could be assigned, to the protons $\mathrm{H}-1, \mathrm{H}-2$ and $\mathrm{H}-4$ of the mono-oxygenated A-ring of 3 [16]. The oxygen was located at C-3 using the $\mathrm{HMBC}^{2} J$ and $^{3} J$ correlations of $\mathrm{H}-1$ at $\delta_{\mathrm{H}}=7.18 \mathrm{ppm}$ with C-4 $\left(\delta_{\mathrm{C}}=116.1 \mathrm{ppm}\right)$; C-5 $\left(\delta_{\mathrm{C}}=134.3 \mathrm{ppm}\right)$ and C-3 $\left(\delta_{\mathrm{C}}=153.7 \mathrm{ppm}\right)$ and those of $\mathrm{H}-2$ at $\delta_{\mathrm{H}}=6.65$ ppm with C-4 $\left(\delta_{\mathrm{C}}=116.1 \mathrm{ppm}\right)$; C-3 $\left(\delta_{\mathrm{C}}=153.7 \mathrm{ppm}\right)$ and C-10 $\left(\delta_{\mathrm{C}}=131.1\right.$ $\mathrm{ppm})$. Thus the A-ring of 1 is totally dehydrogenated, i.e. a benzene ring. The ${ }^{1} \mathrm{H}$ and ${ }^{13} \mathrm{C}$ NMR spectra showed three additional downfield methine signal at $\delta_{\mathrm{H}}=$ 
Table $1 .{ }^{1} \mathrm{H}$ and ${ }^{13} \mathrm{CNMR}$ data (coupling constants $J$ in $\mathrm{Hz}$ ) of compounds $\mathbf{1}, \mathbf{3}$ and $\mathbf{4}$ (chemical shifts $\delta$ in ppm) respectively.

\begin{tabular}{|c|c|c|c|c|c|c|}
\hline \multirow{2}{*}{ Position } & \multicolumn{2}{|l|}{$1^{\mathrm{a}}$} & \multicolumn{2}{|l|}{$3^{\mathrm{b}}$} & \multicolumn{2}{|l|}{$4^{\mathrm{a}}$} \\
\hline & $\delta_{\mathrm{H}}$ & $\delta_{\mathrm{C}}$ & $\delta_{\mathrm{H}}$ & $\delta_{\mathrm{C}}$ & $\delta_{\mathrm{H}}$ & $\delta_{\mathrm{C}}$ \\
\hline 1 & $1.53 \mathrm{~m} ; 2.28 \mathrm{~m}$ & 33.6 & $7.18, \mathrm{~d}, J=8.5$ & 126.8 & $1.83 \mathrm{~m} ; 2.24 \mathrm{~m}$ & 33.9 \\
\hline 2 & $2.29 \mathrm{~m} ; 2.36 \mathrm{~m}$ & 36.4 & $6.65, \mathrm{dd}, J=2.5-8.5$ & 113.5 & $2.58 \mathrm{~m} ; 2.33 \mathrm{~m}$ & 33.5 \\
\hline 3 & - & 199.6 & - & 153.7 & - & 200.1 \\
\hline 4 & $5.82 \mathrm{~s}$ & 124.8 & $6.56, \mathrm{~d}, J=2.5$ & 116.1 & $4.83 \mathrm{~s}$ & 126.1 \\
\hline 5 & - & 165.6 & - & 134.3 & - & 158.6 \\
\hline 6 & $2.08 \mathrm{~m} ; 2.53 \mathrm{~m}$ & 35.7 & $\begin{array}{c}2.88, \mathrm{~d}, J=17.5 ; \\
3.14, \mathrm{dd}, J=3.5-17.5\end{array}$ & 38.7 & 4.46 bs.r & 73.3 \\
\hline 7 & $1.13 \mathrm{~m} ; 1.96 \mathrm{~m}$ & 29.8 & $4.23, \mathrm{bsr}$ & 65.2 & 2.08 , overlap; $1.26 \mathrm{~m}$ & 38.6 \\
\hline 8 & $1.50 \mathrm{~m}$ & 39.8 & $1.64, \mathrm{~m}$ & 41.9 & 2.06, overlap & 29.2 \\
\hline 9 & $0.93 \mathrm{~m}$ & 49.5 & $2.65, \mathrm{~m}$ & 35.7 & $1.02 \mathrm{~m}$ & 53.2 \\
\hline 10 & - & 42.4 & - & 131.1 & - & 70.9 \\
\hline 11 & $1.32 \mathrm{~m} ; 1.94 \mathrm{~m}$ & 25.9 & $1.58 \mathrm{~m} ; 2.10 \mathrm{~m}$ & 25.8 & $1.74 \mathrm{~m} 2[\mathrm{H}]$ & 19.5 \\
\hline 12 & $1.30 \mathrm{~m} ; 1.83 \mathrm{~m}$ & 31.3 & $1.52 \mathrm{~m} ; 1.92 \mathrm{~m}$ & 31.4 & $1.16 \mathrm{~m} ; 1.88 \mathrm{~m}$ & 36.2 \\
\hline 13 & - & 47.3 & - & 50.9 & - & 43.1 \\
\hline 14 & $1.34 \mathrm{~m}$ & 50.6 & $1.84 \mathrm{~m}$ & 46.1 & 1.04 , overlap & 49.9 \\
\hline 15 & $1.54 \mathrm{~m} ; 1.98 \mathrm{~m}$ & 21.4 & $1.61 \mathrm{~m} ; 2.11 \mathrm{~m}$ & 21.1 & $1.38 \mathrm{~m} ; 1.61 \mathrm{~m}$ & 23.2 \\
\hline 16 & $2.26 \mathrm{~m} ; 2.45 \mathrm{~m}$ & 35.2 & $2.18 \mathrm{~m} ; 2.46 \mathrm{~m}$ & 35.7 & $1.46 \mathrm{~m} ; 2.07 \mathrm{~m}$ & 30.4 \\
\hline 17 & - & 220.3 & - & 220.4 & $3.64 \mathrm{t}$ & 81.6 \\
\hline 18 & $0.94 \mathrm{~s}$ & 10.5 & $0.88 \mathrm{~s}$ & 13.9 & $0.82 \mathrm{~s}$ & 10.9 \\
\hline
\end{tabular}

${ }^{\mathrm{a}} 100 \mathrm{MHz} .{ }^{\mathrm{b}} 150 \mathrm{MHz}$.

4.23 (brs) and $\delta_{\mathrm{C}}=65.2 \mathrm{ppm}$, indicating the presence of a second hydroxyl group in the transformed metabolite (3). The position of this hydroxyl group has been deduced on the basis of COSY and HMBC correlations. The HMBC correlations of $\mathrm{H}-6\left(\delta_{\mathrm{H}}=2.88 \mathrm{ppm}, \mathrm{d}, J=17.5 \mathrm{~Hz}\right)$ with C-7 $\left(\delta_{\mathrm{C}}=65.2 \mathrm{ppm}\right)$; C-8 $\left(\delta_{\mathrm{C}}=41.9 \mathrm{ppm}\right)$ and $\mathrm{C}-5\left(\delta_{\mathrm{C}}=134.3 \mathrm{ppm}\right)$ supported the presence of a hydroxyl group at C-7 (Figure 2). This position of the hydroxyl group was also further confirmed by COSY correlations of H-6 $\left(\delta_{\mathrm{H}}=3.05 \mathrm{ppm}, \mathrm{dd}, J=3.5\right.$ $17.5 \mathrm{~Hz}$ ) with H-7 ( $\delta_{\mathrm{H}}=4.17 \mathrm{ppm}$, brs). The stereochemistry of the transformed metabolite 3 was deduced on the basis of NOESY correlations. H-7 ( $\delta_{\mathrm{H}}$ $=4.23 \mathrm{ppm}$, brs) showed NOESY correlations with $\mathrm{H}-14\left(\delta_{\mathrm{H}}=1.84 \mathrm{ppm}, \mathrm{m}\right)$. As $\mathrm{H}-14$ is $\alpha$-oriented in substrate 1 , therefore its NOESY correlation with $\mathrm{H}$-14 suggested $\alpha$-hydroxymethylene at C-7 and the hydroxylation at C-7 was deduced to be $\beta$-oriented (Figure 3). Finally, metabolite 2 was identified as 3,7 $\beta$-dihydroxy-19-norandrost-1,3,5-trien-17-one.

Metabolite 4 was obtained as a yellow solid, m.p. $=253^{\circ} \mathrm{C}-258^{\circ} \mathrm{C}$, soluble in $\mathrm{CDCl}_{3}$ The HRMS ((-)-FAB) spectrum of 4 showed the quasi-molecular ion peak $[\mathrm{M}-\mathrm{H}]^{-}$at $\mathrm{m} / \mathrm{z}=305.1719$ indicating the formula $\mathrm{C}_{18} \mathrm{H}_{26} \mathrm{O}_{4}$ (calcd. $\mathrm{m} / \mathrm{z}=$ 305.1747), consistent with six degrees of unsaturation. This mass indicated that 


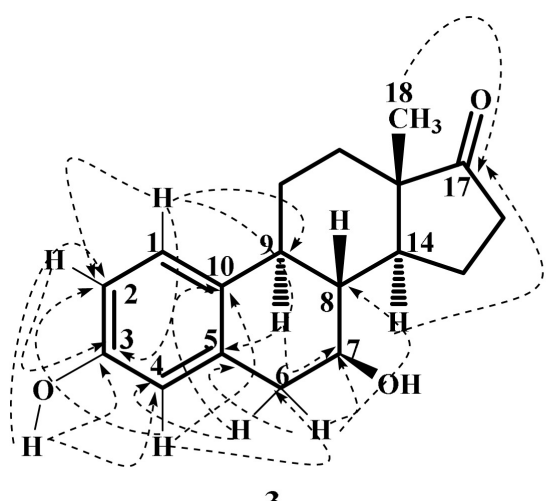

3

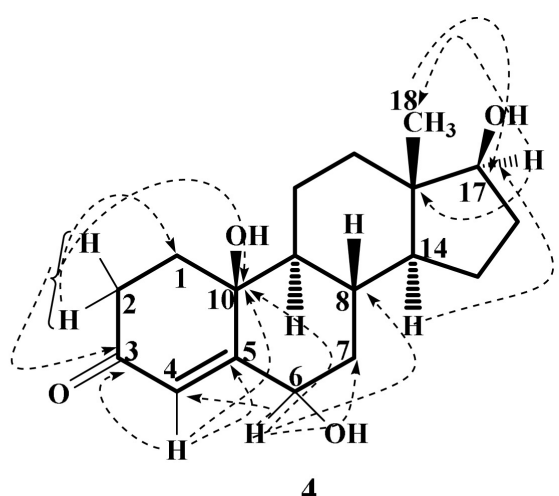

4

Figure 2. KeyHMBC correlations in compounds 3 and 4.

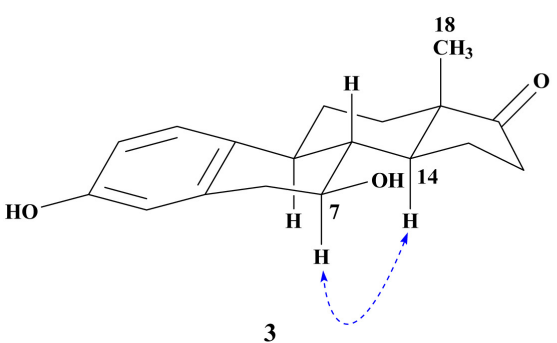

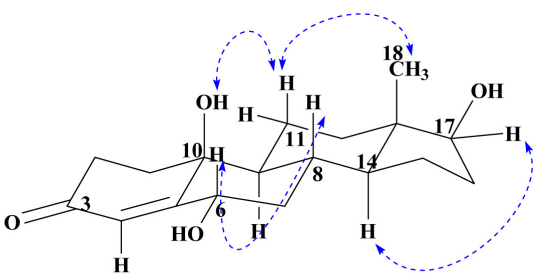

4

Figure 3. KeyNOESY correlations in compounds $\mathbf{3}$ and 4.

compound 4 contains three additional $\mathrm{OH}$ groups as compared to compound 1 $(\mathrm{m} / \mathrm{z}=272.1)$. The IR bands at 3418 and $1657 \mathrm{~cm}^{-1}$ indicated the presence of $-\mathrm{OH}$ and ketone functionalities, respectively. Compound 4 showed characteristic fluorescence in the UV spectrum at 229 and $243 \mathrm{~nm}$, which indicates the presence of a conjugated ketone. The ${ }^{1} \mathrm{H}$ NMR spectrum displayed signals of two new methine protons at $\delta_{\mathrm{H}}=3.64 \mathrm{ppm}(\mathrm{t}, J=8.1 \mathrm{~Hz})$ and $\delta_{\mathrm{H}}=3.64 \mathrm{ppm}(\mathrm{brs})$ (Table 1$)$. The presence of a new quaternary $\left(\delta_{\mathrm{C}}=70.9 \mathrm{ppm}\right)$ and two methine carbons $\left(\delta_{\mathrm{C}}=73.3,81.6 \mathrm{ppm}\right)$ in the ${ }^{13} \mathrm{C}$ NMR spectrum further supported the trihydroxylation of the substrate 1 (Table 1 ). The position of these hydroxyl groups was deduced using the HMBC spectrum. Protons $\mathrm{H}-2\left(\delta_{\mathrm{H}}=2.32,2.58\right.$ $\mathrm{ppm})$ and $\mathrm{H}-4\left(\delta_{\mathrm{H}}=5.83 \mathrm{ppm}\right)$ showed $\mathrm{HMBC}$ correlations with C-10 $\left(\delta_{\mathrm{C}}=70.9\right.$ $\mathrm{ppm})$, which indicated a hydroxylation at C-10. H-4 $\left(\delta_{\mathrm{H}}=5.83 \mathrm{ppm}\right)$ and $\mathrm{H}-7$ $\left(\delta_{\mathrm{H}}=2.05 \mathrm{ppm}\right)$ showed $\mathrm{HMBC}$ correlations with the new C-6 atom $\left(\delta_{\mathrm{C}}=70.8\right.$ $\mathrm{ppm})$ which indicated a second hydroxylation at C-6. H-18 $\left(\delta_{\mathrm{H}}=0.82 \mathrm{ppm}\right)$ and $\mathrm{H}-14\left(\delta_{\mathrm{H}}=1.04 \mathrm{ppm}\right)$ showed HMBC correlations with C-17 $\left(\delta_{\mathrm{C}}=81.6 \mathrm{ppm}\right)$, hence the third hydroxyl group occurs at $\mathrm{C}-17$ (Figure 2). NOESY correlations of $\mathrm{H}-11\left(\delta_{\mathrm{H}}=1.74 \mathrm{ppm}\right)$ and $\mathrm{H}-18\left(\delta_{\mathrm{H}}=0.92 \mathrm{ppm}\right)$ with $\mathrm{OH}\left(\delta_{\mathrm{H}}=5.04 \mathrm{ppm}\right)$ at $\mathrm{C}-10$ were used to support the stereochemistry of the hydroxyl group at C-10 as $\beta$. H-8 $-(-\beta)$ at $\delta_{\mathrm{H}}=2.06 \mathrm{ppm}$ showed NOESY correlations with $\mathrm{H}-6\left(\delta_{\mathrm{H}}=\right.$ $4.46 \mathrm{ppm})$. Therefore, $\alpha-\mathrm{OH}$ was placed at C- 6 . In addition, the NOESY correlation between $\mathrm{H}-14\left(\delta_{\mathrm{H}}=1.04 \mathrm{ppm}\right)$ with $\mathrm{H}-17\left(\delta_{\mathrm{H}}=3.64 \mathrm{ppm}\right)$ allowed us to assign a $\beta$-orientation of $\mathrm{OH}$ at $\mathrm{C}-17$ (Figure 3 ). Thus the metabolite 4 was identi- 
fied as $6 \alpha, 10 \beta, 17 \beta$-trihydroxy-19-nor-4-androsten-3-one.

The transformed compounds and substrate 1 were screened for their potential against enzymes involved in ulcer and viral diseases by various in vitro biological assays (Table 2).

When the activities of compounds 1-6 were screened against urease, compound 3 showed remarkable urease inhibition with an $\mathrm{IC}_{50}$ value of $10.2 \pm 0.28$ $\mu \mathrm{m}$ as compared to the standard thiourea with $\mathrm{IC}_{50}=21.6 \pm 0.12 \mu \mathrm{m}$. This clearly indicates that compound $\mathbf{3}$ is more potent than thiourea. In addition, compound 2 also showed excellent urease inhibition activity with an $\mathrm{IC}_{50}$ value of $23.7 \pm 0.17 \mu \mathrm{M}$.

With regard to chymotrypsin inhibitory activity, compound 4 exhibits excellent protease inhibitor potential against chymotrypsin with an $\mathrm{IC}_{50}$ value of $6.4 \pm$ $0.19 \mu \mathrm{m}$ as compared to standard chymostatin with $\mathrm{IC}_{50}=5.7 \pm 0.14 \mu \mathrm{m}$. In addition, compounds 5 and 6 also show promising activity with IC $_{50}$ value of $15.6 \pm$ 0.46 and $18.4 \pm 0.65 \mu \mathrm{M}$, respectively. It shows that these compounds 4-6 can be potential serine inhibitors. NS3 serine protease of HCV and HIV protease are key enzymes that catalyse replication of virus and are the target for anti-HCV and anti-HIV drugs [17], therefore compound 4 can be effective as anti-viral compounds and can be further used for anti-viral studies in future but compounds 5 and 6 required incomparably higher concentration than standard chymostatin to inhibit the enzyme with less potency.

\section{Materials and Methods}

\subsection{General Experimental Conditions}

Norandrostenedione (1) $\left(\mathrm{C}_{18} \mathrm{H}_{24} \mathrm{O}_{2}\right)$ was obtained from Sigma-Aldrich (cat no. 74640, USA). Media constituents including Sabouraud dextrose agar were acquired from Sigma-Aldrich (cat no. 146392, Germany). The quality of the substrate purity (1) was checked by thin layer chromatography (TLC, silica-coated (PF254)). Silica gel (70 - 230 mesh) column chromatography was performed for

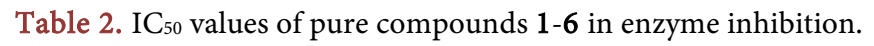

\begin{tabular}{ccc}
\hline \multirow{2}{*}{ Compounds } & \multicolumn{2}{c}{ IC $_{50} \pm$ MSE (values in MM) } \\
\cline { 2 - 3 } & Urease inhibition & Chymotrypsin inhibition \\
\hline $\mathbf{1}$ & $81.2 \pm 0.28^{\mathrm{a}}$ & $00 \pm 0.00^{\mathrm{a}}$ \\
$\mathbf{3}$ & $23.7 \pm 0.17^{\mathrm{b}}$ & $75.3 \pm 0.26^{\mathrm{b}}$ \\
$\mathbf{4}$ & $10.2 \pm 0.28^{\mathrm{c}}$ & $61.2 \pm 0.24^{\mathrm{c}}$ \\
$\mathbf{5}$ & $78.5 \pm 0.27^{\mathrm{d}}$ & $6.4 \pm 0.19^{\mathrm{d}}$ \\
$\mathbf{6}$ & $76.3 \pm 0.46^{\mathrm{e}}$ & $15.6 \pm 0.46^{\mathrm{e}}$ \\
Thiourea & $00 \pm 0.00^{\mathrm{f}}$ & $18.4 \pm 0.65^{\mathrm{f}}$ \\
Chymostatin & $21.6 \pm 0.12^{\mathrm{g}}$ & - \\
\hline
\end{tabular}

a,b,c,e,f,g On the same column, values with different letters are differ significantly $(p>0.05)$ to the standard the control. MSE: Mean standard error. 
fractionation of crude extract. Fractions were finally purified through recycling with preparative RP-HPLC (LC-908, Japan), equipped with JAIGEL-ODS-L-80 $(\mathrm{L}=250 \mathrm{~mm}$, I.D. $=\mathrm{T} 20 \mathrm{~mm})$. HR-FAB-MS and HR-IE-MS were recorded on Jeol JMS-600H mass spectrometer. 1D-, and 2D-NMR of compounds 1-6 were performed in deuterated chloroform $\left(\mathrm{CDCl}_{3}\right)$ on Bruker Avance spectrometers AMX (400 and $100 \mathrm{MHz}$ ) with tetramethylsilane as an internal standard. A Büchi M-560 apparatus (model M-560) was used for determining the melting points. Optical rotations of isolated compounds were measured on a JASCO P-2000 polarimeter. UV absorbance ( $\lambda$ in $\mathrm{nm}$ ) was done on a Shimadzu UV 240 spectrophotometer (Shimadzu Corporation, Tokyo, Japan; model: Evolution-300). Infrared (IR) spectra (in $\mathrm{cm}^{-1}$ ) were recorded with an FT-IR-8900 spectrophotometer.

\subsection{Fermentation of Norandrostenedione (1) with Fusarium lini and Isolation of Metabolites}

\subsubsection{Microbial Culture and Media Preparation}

Fungus culture was obtained from the international culture collection centre Northern Regional Research Laboratory (NRRL). The fungus used was Fusarium lini NRRL 2204 which was grown on Sabouraud dextrose agar (SDA) and preserved at $T=4^{\circ} \mathrm{C}$. The ingredients used for the preparation of the culture medium $(1 \mathrm{~L})$ for the microorganism Fusarium lini was as follows: $5.0 \mathrm{~g}$ peptone, $5.0 \mathrm{~g} \mathrm{NaCl}, 10.0 \mathrm{~g}$ glucose, $5.0 \mathrm{~g}$ potassium dihydrogen phosphate, and $10.0 \mathrm{~mL}$ glycerol in $1 \mathrm{~L}$ of distilled water [5] [7] [14].

\subsubsection{Fermentation, Extraction and Purification of Norandrostenedione (1) with Fusarium lini}

The biotransformation experiment was performed in two steps, on a small and a large scale. Based on small-scale screening results, $20 \mathrm{~L}$ of culture medium for the growth of F. Lini was prepared by using the above mentioned media ingredients in $18 \mathrm{~L}$ of distilled water, and transferred to 10 conical flasks of $5 \mathrm{~L}$ (each flask containing $2 \mathrm{~L}$ of medium). They were cotton-plugged, autoclaved at $T=$ $121^{\circ} \mathrm{C}$, cooled to room temperature and inoculated with seed flasks of $F$. lini under aseptic conditions on a shaker $(121 \mathrm{rpm})$ at $20^{\circ} \mathrm{C} \pm 2^{\circ} \mathrm{C}$ until a good biomass (4 days) was obtained. After mature growth of F. lini, $2.5 \mathrm{~g}$ of norandrostenedione (1) $\left(\mathrm{C}_{18} \mathrm{H}_{24} \mathrm{O}_{2}\right)$ was dissolved in $80 \mathrm{~mL}$ of acetone, and transferred to the flasks ( $8 \mathrm{~mL}$ in each flask). The flasks were placed on a shaker for 15 days at $26^{\circ} \mathrm{C} \pm 2{ }^{\circ} \mathrm{C}$. After 15 days of incubation, the reaction was stopped by adding $1 \mathrm{~L}$ of ethyl acetate to each flask. All culture flasks were combined and filtered to remove mycelia. The aqueous filtrate was extracted thrice with EtOAc and after drying with sodium sulfate, concentrated under reduced pressure with a rotavapor. This operation yielded $4.5 \mathrm{~g}$ yellow gummy crude which was subjected to silica-gel (0.032 - 0.063 mesh) column chromatography (CC) with a mobile phase of hexanes-acetone (100:0; 95:5; 90:10;85:15; 80:20;75:25; 70:30; 65:35; $60: 40 ; 55: 45$ and $50: 50)$. 
Thin layer chromatography (TLC) was used to determine the profile of different fractions. Three fractions (F-1 to F-3) were obtained from column chromatography. Compounds were further purified on reverse phase recycling HPLC. The fraction F-3 was re-chromatographed on silica gel and yielded compounds $4(\mathrm{RT}=16 \mathrm{~min}, 18.7 \mathrm{mg}), 5(\mathrm{RT}=20 \mathrm{~min}, 33.5 \mathrm{mg})$ and $6(\mathrm{RT}=24$ min, $41.5 \mathrm{mg})$, on elution with methanol and water (MeOH- $\left.\mathrm{H}_{2} \mathrm{O} 90: 10\right)$. Compounds $2(\mathrm{RT}=21 \mathrm{~min}, 18.5 \mathrm{mg}$ ) and $3(\mathrm{RT}=27 \mathrm{~min}, 24.5 \mathrm{mg})$, were purified from fraction 3 through purification on reverse phase HPLC eluted with ( $\mathrm{MeOH}-\mathrm{H}_{2} \mathrm{O}$ 80:20).

Compound (3): White solid, m.p. $=152^{\circ} \mathrm{C}-155^{\circ} \mathrm{C} .[\alpha]_{D}^{25}=+3380.4(c=$ 0.003, MeOH). UV (MeOH, nm): $\lambda_{\max }\left(\log \varepsilon_{\max }\right)=230(1.41), 243$. IR $\left(\mathrm{KBr}, \mathrm{cm}^{-1}\right)$ : $v=3405$ (-OH stretching), $1720(\mathrm{C}=\mathrm{O}$ stretching), $1657(\mathrm{C}=\mathrm{C})$. HRMS ((+)-EI): $m / z=286.1563$ (calcd. 286.1567 for $\left.\mathrm{C}_{18} \mathrm{H}_{22} \mathrm{O}_{3},[\mathrm{M}]^{+}\right) .{ }^{1} \mathrm{H}$ NMR $\left(\mathrm{CDCl}_{3}, 600\right.$ $\mathrm{MHz})$ and ${ }^{13} \mathrm{C} \mathrm{NMR}\left(\mathrm{CDCl}_{3}, 150 \mathrm{MHz}\right)$ : Table 1.

Compound (4): Yellow solid, m.p. $=253^{\circ} \mathrm{C}-258^{\circ} \mathrm{C} ;[\alpha]_{25}^{D}=+3380.4(\mathrm{c}$ 0.003, MeOH). UV $\lambda_{\max }(\mathrm{MeOH}, \mathrm{nm}): \lambda_{\max }\left(\log \varepsilon_{\max }\right)=243(2.40), 229$. IR $\left(\mathrm{CHCl}_{3}, \mathrm{~cm}^{-1}\right): v_{\max }=3418$ (-OH stretching), 1657 (C=O stretching). HRMS ((-)-FAB): $m / z: 305.1719[\mathrm{M}-\mathrm{H}]^{-}$(calcd. for $\mathrm{C}_{18} \mathrm{H}_{26} \mathrm{O}_{4}^{+}$306.1747); EI-MS ((+)-EI): $\mathrm{m} / \mathrm{z}$ (relative intensity, \%) = $306(100)[\mathrm{M}]^{+}, 259$ (10), $138(18.8), 133$ (16), 91 (14.4). ${ }^{1} \mathrm{H}$ NMR $\left(\mathrm{CDCl}_{3}, 400 \mathrm{MHz}\right)$ : Table 1; ${ }^{13} \mathrm{C} \mathrm{NMR}\left(\mathrm{CDCl}_{3}, 100\right.$ MHz): Table 1.

3-Hydroxy-19-norandrost-1,3,5-trien-17-one (2): Yellow solid; m.p. = $183^{\circ} \mathrm{C}-189^{\circ} \mathrm{C} ;[\alpha]_{25}^{D}=-338.4(\mathrm{c} 0.03, \mathrm{MeOH}) ; \mathrm{UV} \lambda_{\max }(\mathrm{MeOH} \log \varepsilon 2.38) \mathrm{nm}:$ 230 and 281 [5]. IR $v_{\max }\left(\mathrm{CHCl}_{3}, \mathrm{~cm}^{-1}\right): 3278$ (-OH stretching); 1709 and 1618 (C=O stretching). ${ }^{1} \mathrm{H}$ NMR $\left(\mathrm{CDCl}_{3}, 500 \mathrm{MHz}\right): \delta_{\mathrm{H}} 7.14(1 \mathrm{H}, \mathrm{d}, J=8.5 \mathrm{~Hz}, \mathrm{H}-1)$; $6.62(1 \mathrm{H}, \mathrm{dd}, J=2.5-8.5 \mathrm{~Hz}, \mathrm{H}-2) ; 6.56(1 \mathrm{H}, \mathrm{d}, J=2.5 \mathrm{~Hz}, \mathrm{H}-4) ; 2.28(2 \mathrm{H}, \mathrm{d}, J=$ $17.5 \mathrm{~Hz}, \mathrm{H}-6) ; 1.43$ (1H, m, H-7 $\alpha$ ); 1.99 (1H, m, H-7 $\beta) ; 1.57$ (1H, m, H-8); 2.23

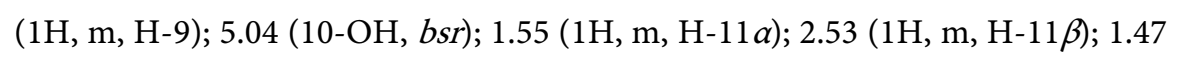
$(1 \mathrm{H}, \mathrm{m}, \mathrm{H}-12 \alpha) ; 1.94(1 \mathrm{H}, \mathrm{m}, \mathrm{H}-12 \beta) ; 1.51(1 \mathrm{H}, \mathrm{m}, \mathrm{H}-14) ; 1.64(1 \mathrm{H}, \mathrm{m}, \mathrm{H}-15 \alpha)$; $2.04(1 \mathrm{H}, \mathrm{m}, \mathrm{H}-15 \beta) ; 2.13(1 \mathrm{H}, \mathrm{m}, \mathrm{H}-16 \alpha) ; 2.48(1 \mathrm{H}, \mathrm{m}, \mathrm{H}-16 \beta) ; 0.91(3 \mathrm{H}, s) .{ }^{13} \mathrm{C}$ NMR (125 MHz, CDCl $)$ : $\delta_{\mathrm{C}} 126.5$ (C-1); 112.8 (C-2); 153.4 (C-3); 115.2 (C-4); 138.1 (C-5); 29.4 (C-6); 26.8 (C-7); 38.3 (C-8); 43.9 (C-9); 132.1 (C-10); 26.3 (C-11); 31.5 (C-12); 48.9 (C-13); 50.4 (C-14); 21.5 (C-15); 35.8 (C-16); 221.2 (C-17); 13.8 (C-18). HREI-MS m/z. $270.1617 \quad[\mathrm{M}]^{+}$(calcd. for $\mathrm{C}_{18} \mathrm{H}_{22} \mathrm{O}_{2}^{+}$ 270.1620).

$10 \beta, 17 \beta$-dihydroxy-19-nor-4-androsten-3-one (5): White solid; m.p. = $214^{\circ} \mathrm{C} ;[\alpha]_{25}^{D}+3380.4(\mathrm{c} 0.003, \mathrm{MeOH})$; UV $\lambda_{\max }(\mathrm{MeOH} \log \varepsilon 3.32) \mathrm{nm}: 230$, and 260. IR $v_{\max }\left(\mathrm{KBr}, \mathrm{cm}^{-1}\right): 3395$ (-OH stretching); $1661\left(\mathrm{C}=\mathrm{O}\right.$ stretching). ${ }^{1} \mathrm{H}$ NMR $\left(\mathrm{CDCl}_{3}, 400 \mathrm{MHz}\right): \delta_{\mathrm{H}} 1.98(1 \mathrm{H}, \mathrm{m}, \mathrm{H}-1 \alpha) ; 2.19(1 \mathrm{H}, \mathrm{m}, \mathrm{H}-1 \beta) ; 2.35(1 \mathrm{H}$, m, H-2 $\alpha) ; 2.51(1 \mathrm{H}, \mathrm{m}, \mathrm{H}-2 \beta)$; $5.77(1 \mathrm{H}, s, \mathrm{H}-4) ; 2.24(1 \mathrm{H}, \mathrm{m}, \mathrm{H}-6 \alpha) ; 2.65(1 \mathrm{H}$,

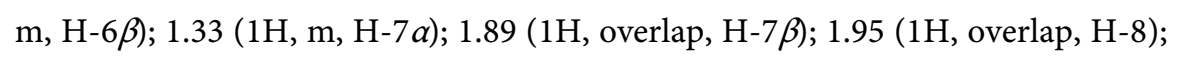
$1.12(1 \mathrm{H}, b s r, \mathrm{H}-9) ; 1.74(2 \mathrm{H}, \mathrm{m}, \mathrm{H}-11) ; 1.11(1 \mathrm{H}, \mathrm{m}, \mathrm{H}-12 \alpha) ; 1.98(1 \mathrm{H}, \mathrm{m}$, $\mathrm{H}-12 \beta) ; 1.32(1 \mathrm{H}$, overlap, $\mathrm{H}-14) ; 1.58(1 \mathrm{H}, \mathrm{m}, \mathrm{H}-15 \alpha) ; 1.97(1 \mathrm{H}, \mathrm{m}, \mathrm{H}-15 \beta)$; 
$2.10(1 \mathrm{H}, \mathrm{m}, \mathrm{H}-16 \alpha) ; 2.50(1 \mathrm{H}, \mathrm{m}, \mathrm{H}-16 \beta) ; 3.64(1 \mathrm{H}, t, \mathrm{H}-17) ; 0.92(3 \mathrm{H}, s) ; 5.04$ $(1 \mathrm{H}, \mathrm{m}, 10-\mathrm{OH}) ;{ }^{13} \mathrm{C}$ NMR $\left(100 \mathrm{MHz}, \mathrm{CDCl}_{3}\right): \delta_{\mathrm{C}} 33.8(\mathrm{C}-1) ; 33.6(\mathrm{C}-2) ; 198.9$ (C-3); 124.9 (C-4); 164.1 (C-5); 31.9 (C-6); 31.3 (C-7); 35.3 (C-8); 52.6 (C-9); 70.4 (C-10); 19.9 (C-11); 36.1 (C-12); 43.1 (C-13); 50.1 (C-14); 23.3 (C-15); 30.5 (C-16); 81.6 (C-17); 10.8 (C-18). HREI-MS m/z. $290.1 \mathrm{MM}^{+}$(calcd. for $\mathrm{C}_{18} \mathrm{H}_{26} \mathrm{O}_{3}^{+}$290.1).

10 $\beta$-hydroxy-19-nor-4-androsten-3,17-dione (6): White solid; m.p. = $205^{\circ} \mathrm{C}-210^{\circ} \mathrm{C},\left(203^{\circ} \mathrm{C}-208^{\circ} \mathrm{C}\right)[15] ;[\alpha]_{25}^{D}=-3380.4(\mathrm{c} 0.003, \mathrm{MeOH})$. IR $v_{\max }$ $\left(\mathrm{KBr}, \mathrm{cm}^{-1}\right): 3402$ (-OH stretching); 1720 and 1665 (C=O stretching). ${ }^{1} \mathrm{H}$ NMR $\left(\mathrm{CDCl}_{3}, 400 \mathrm{MHz}\right): \delta_{\mathrm{H}} 1.98(1 \mathrm{H}, \mathrm{m}, \mathrm{H}-1 \alpha) ; 2.18(1 \mathrm{H}, \mathrm{m}, \mathrm{H}-1 \beta) ; 2.31(1 \mathrm{H}, \mathrm{m}$, $\mathrm{H}-2 \alpha) ; 2.54(1 \mathrm{H}, \mathrm{m}, \mathrm{H}-2 \beta) ; 5.77(1 \mathrm{H}, s, \mathrm{H}-4) ; 2.21(1 \mathrm{H}, \mathrm{m}, \mathrm{H}-6 \alpha) ; 2.68(1 \mathrm{H}, \mathrm{m}$, $\mathrm{H}-6 \beta) ; 1.31(1 \mathrm{H}, \mathrm{m}, \mathrm{H}-7 \alpha) ; 1.81(1 \mathrm{H}$, overlap, $\mathrm{H}-7 \beta) ; 1.91$ (1H, overlap, $\mathrm{H}-8)$; $1.17(1 \mathrm{H}, b s r, \mathrm{H}-9) ; 1.70(2 \mathrm{H}, \mathrm{m}, \mathrm{H}-11) ; 1.13(1 \mathrm{H}, \mathrm{m}, \mathrm{H}-12 \alpha) ; 2.01(1 \mathrm{H}, \mathrm{m}$,

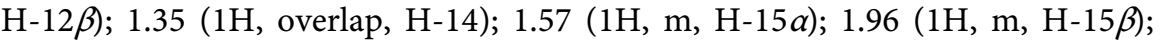
$2.12(1 \mathrm{H}, \mathrm{m}, \mathrm{H}-16 \alpha) ; 2.54(1 \mathrm{H}, \mathrm{m}, \mathrm{H}-16 \beta) ; 3.66(1 \mathrm{H}, t, \mathrm{H}-17) ; 0.92(3 \mathrm{H}, s) ;{ }^{13} \mathrm{C}$ NMR $\left(100 \mathrm{MHz}, \mathrm{CDCl}_{3}\right): \delta_{\mathrm{C}} 33.7(\mathrm{C}-1) ; 33.5(\mathrm{C}-2) ; 198.7$ (C-3); 124.9 (C-4); 163.7(C-5); 31.7 (C-6); 31.1 (C-7); 34.8 (C-8); 52.5 (C-9); 70.3 (C-10); 19.6 (C-11); 30.5 (C-12); 47.5 (C-13); 50.4 (C-14); 21.7 (C-15); 35.7 (C-16); 220.3 (C-17); 13.6 (C-18) HREI-MS m/z. $288.1734[\mathrm{M}]^{+}$(calcd. for $\mathrm{C}_{18} \mathrm{H}_{24} \mathrm{O}_{3}^{+}$ 288.1725).

\subsection{Urease Inhibition Assay}

Reaction mixtures comprising $25 \mu \mathrm{L}$ of enzyme (Jack bean Urease) solution and $55 \mu \mathrm{L}$ of buffers containing $100 \mathrm{~mm}$ urea were incubated with $5 \mu \mathrm{L}$ of test compounds ( $1 \mu \mathrm{m}$ concentration) at $T=30^{\circ} \mathrm{C}$ for $15 \mathrm{~min}$ in 96 -well plates. Urease activity was determined by measuring ammonia production using the indophenol method as described by Khan [18]. Briefly, $45 \mu \mathrm{L}$ of phenol reagent ( $1 \% \omega / V$ phenol and $0.005 \% w / V$ sodium nitroprusside) and $70 \mu \mathrm{L}$ of alkali reagent $(0.5 \%$ $w / v \mathrm{NaOH}$ and $0.1 \%$ active chloride $\mathrm{NaOCl}$ ) were added to each well. The increasing absorbance at $630 \mathrm{~nm}$ was measured after $50 \mathrm{~min}$, using a microplate reader (Molecular Device, USA). All reactions were performed in triplicate in a final volume of $200 \mu \mathrm{L}$. The results (change in absorbance per min) were processed by using SoftMaxPro software (Molecular Device, USA). Assays were performed at $\mathrm{pH}=8.2\left(0.01 \mathrm{~m} \mathrm{~K}_{2} \mathrm{HPO}_{4} \cdot 3 \mathrm{H}_{2} \mathrm{O}, 1 \mathrm{mM}\right.$ EDTA and $\left.0.01 \mathrm{~m} \mathrm{LiCl}\right)$. Percentage inhibition was calculated from the formula $100-\left(\mathrm{OD}_{\text {testwell }} / \mathrm{OD}_{\text {control }}\right) \times 100 \%$. where OD stands for optical density. Thiourea was used as the standard inhibitor of urease.

\subsection{In Vitro $\alpha$-Chymotrypsin Assay}

The $\alpha$-chymotrypsin inhibitory activity was determined using a previously described method [19]. Briefly, $\alpha$-chymotrypsin (9 units per $\mathrm{mL}$ in $50 \mathrm{~mm}$ Tris- $\mathrm{HCl}$ buffer, $\mathrm{pH}=7.6$; Sigma Chemical Co. USA) was pre-incubated with the test compounds at a concentration varying from 5 to $500 \mu \mathrm{m}$ for $20 \mathrm{~min}$ at 
$T=25^{\circ} \mathrm{C} .100 \mu \mathrm{L}$ of substrate solution $(N$-succinyl-phenylalanine- $p$-nitroanilide, $0.01-0.06 \mathrm{~mm}$ in $50 \mathrm{~mm}$ Tris- $\mathrm{HCl}$ buffer, $\mathrm{pH}=7.6$ ) was added to start the enzyme reaction. The absorbance of released $p$-nitroaniline was continuously monitored at $410 \mathrm{~nm}$ until a considerable colour change was achieved. The final DMSO concentration in the reaction mixture was $7 \%$. Best inhibition was found at concentration $3.02 \times 10^{-5} \mathrm{~g} / 100 \mu \mathrm{L}$. The percentage (\%) inhibition was calculated as $(E-S) / E \times 100 \%$ where $E$ is the activity of the enzyme without test compound, and $S$ is the activity of the enzyme in the presence of the test compound. The concentrations of test compounds that inhibited the hydrolysis of substrate up to $50 \%\left(\mathrm{IC}_{50}\right)$ were determined by monitoring the effect of various concentrations of these compounds in the assays. The $\mathrm{IC}_{50}$ values were then calculated using the EZ-Fit Enzyme Kinetics program (Version PerrellaScientific Inc., Amherst, USA).

\subsection{Statistical Analysis}

The data are presented as the mean \pm one standard deviation (SD). One-way ANOVA followed by Dennett's test, as specified, was performed using GraphPad Prism, version 7.00 (GraphPad Software, San Diego, California, USA). One-way ANOVA was used to compare the control and test groups. Values $p \leq 0.05$ were considered to be statistically significant.

\section{Conclusion}

In conclusion, microbial transformation of the androgenic steroid norandrostenedione (1) with Fusarium lini yielded two new metabolites 3 and 4, along with three known metabolites 2, 5 and 6 . Biocatalytic transformation of 1 with Fusarium lini provided an efficient route for the mono-hydroxylation(10- $\beta$ ) in metabolite 6 , dihydroxylation (10- $\beta$ and $17-\beta)$ in metabolite 5 , trihydroxylation (6- $\alpha, 10-\beta$ and 17- $\beta$ ) in metabolite 4 and aromatisation of A-ring in metabolite 2 and 3. We can conclude on the basis of literature and previous studies that, Fusarium lini possess enzymes such as monooxygenase, dioxygenase and trioxygenase systems, which catalyze the $\alpha$ - and $\beta$-hydroxylation, and also dehydrogenases which catalyse the dehydrogenation at various positions of the steroidal skeleton. In addition, compounds 2 and 3 show potent growth inhibition against drug-resistant strains of urease. Compounds 4, 5 and 6 show good chymotrypsin activity. This study indicates that special attention should be paid to the biotransformation process as it can contribute to the development of new bioactive compounds.

\section{Acknowledgements}

We would like to extend our sincerest gratitude to Dr. Panjwani Center for Molecular Medicine and Drug Research and H.E.J. Research Institute of Chemistry, International Center for Chemical and Biological Sciences, University of Karachi, Karachi (Pakistan) under The Word Academy of Sciences (TWAS) post- 
doctoral fellowship fr number 3240299142 and post-graduate fellowship fr number 3240299153 for providing facilities for this study.

\section{Competing Interests}

The authors declare that they have no conflict of interests.

\section{References}

[1] Venisetty, R.K. and Cidd, V. (2003) Application of Microbial Biotransformation for the New Drug Discovery Using Natural Drugs as Substrates. Current Pharmaceutical Biotechnology, 4, 153-167. https://doi.org/10.2174/1389201033489847

[2] Borges, K.B., Borges, W.D.S., Duran-Patron, R., Pup, M.T., Bonato, P.S. and Collado, I.G. (2009) Stereoselective Biotransformations Using Fungi as Biocatalysts. Tetrahedron: Asymmetry, 20, 385-397. https://doi.org/10.1016/j.tetasy.2009.02.009

[3] Liu, J.H. and Yu, B.Y. (2010) Biotransformation of Bioactive Natural Products for Pharmaceutical Lead Compounds. Current Organic Chemistry, 14, 1400-1406. https://doi.org/10.2174/138527210791616786

[4] Malik, S.A., Rabia, F. and Nusrat, H., Atia-tul-Wahab, Atta-ur-Rahman and Choudhary, M.I. (2016) Three New Analogues of Androgenic Drug Mesterolone through Biotransformation with Cunninghamella blakseleeana. Journal of Molecular Catalysis B: Enzymatic, 133, S395-S399. https://doi.org/10.1016/j.molcatb.2017.03.001

[5] Baydoun, E., Atia-tul-Wahab, M.H., Malik, S.A., Malik, R., Smith C. and Choudhary, M.I. (2016) Microbial Transformation of Danazol with Cunninghamella blakesleeana and Anti-Cancer Activity of Danazol and Its Transformed Products. Steroids, 105, 121-127. https://doi.org/10.1016/j.steroids.2015.11.010

[6] Al-Aboudi, A., Muneeb Kana'an, B., Abu Zarga, M., Bano, S., Atia-tul-Wahab, Javed, K. and Choudhary, M.I. (2017) Fungal Biotransformation of Diuretic and Antihypertensive Drug Spironolactone with Gibberella fujikuroi, Curvularia lunata, Fusarium lini, and Aspergillus alliaceus. Steroids, 128, 15-22. https://doi.org/10.1016/j.steroids.2017.10.003

[7] Atia-tul-Wahab, Siddiqui, M., Ibrahim, I., Hussain, A., Ajandouz, E.H., Hijazi, A., Baydoun, E. and Choudhary, M.I. (2018) Cunninghamella blakesleeana-Mediated Biotransformation of a Contraceptive Drug, Desogestrel and Anti-MDR-Staphylococcus aureus Activity of Its Metabolites. Bioorganic Chemistry, 77, 152-158. https://doi.org/10.1016/j.bioorg.2017.12.027

[8] Jepson, J.H., Gardner, F.H., Gorshein, D. and Hait, W.M. (1973) Current Concepts of Action of Androgenic Steroids on Erythropoiesis. Journal of Pediatrics, 83, 703-708. https://doi.org/10.1016/S0022-3476(73)80253-7

[9] Burne, R.A. and Chen, Y.M. (2000) Bacterial Ureases in Infectious Diseases. Microbes and Infection, 2, 533-542. https://doi.org/10.1016/S1286-4579(00)00312-9

[10] Weeks, D.L., Eskandari, S., Scott, D.R. and Sachs, G. (2002) AH+-Gated Urea Channel: The Link between Helicobacter pylori Urease and Gastric Colonization. Science, 287, 482-485. https://doi.org/10.1126/science.287.5452.482

[11] Rutherford, J.C. (2014) The Emerging Role of Urease as a General Microbial Virulence Factor. PLoS Pathogens, 10, e1004062.

https://doi.org/10.1371/journal.ppat.1004062

[12] Chandanwale, A., Langade, D., Sonawane, D. and Gavai, P. (2017) A Randomized, Clinical Trial to Evaluate Efficacy and Tolerability of Trypsin: Chymotrypsin as 
Compared to Serratiopeptidase and Trypsin: Bromelain: Rutoside in Wound Management. Advances in Therapy, 34, 180-198.

https://doi.org/10.1007/s12325-016-0444-0

[13] White, M.J.V., Glenn, M. and Gomer, R.H. (2013) Trypsin Potentiates Human Fibrocyte Differentiation. PLOS ONE, 8, e70795.

https://doi.org/10.1371/journal.pone.0070795

[14] Fodouop Chegaing, S.P., Mboussaah Kengni, A.D., Siddiqui, M., Fowa, A.B., Gatsing, D. and Choudhary, M.I. (2020) Fungal Transformation of Norandrostenedione with Cunninghamella blakesleeana and Anti-Bacterial Activity of the Transformed Products. Steroids, 162, Article ID: 108679.

https://doi.org/10.1016/j.steroids.2020.108679

[15] Shahid, A., Aziz, A., Noureen, S., Ahmed, M., Yousuf, S. and Choudhary, M.I. (2018) Biotransformation, Spectroscopic Investigation, Crystal Structure and Electrostatic Properties of 3,7a-Dihydroxyestra-1,3,5-(10)-trien-17-one Monohydrate Studied Using Transferred Electron-Density Parameters. Acta Crystallographica, C74, 534-541. https://doi.org/10.1107/S2053229618004953

[16] Kolet, S.P., Niloferjahan, S., Haldar, S., Gonnade, R. and Thulasiram, H.V. (2013) Biocatalyst Mediated Production of $6 \beta, 11 \alpha$-Dihydroxy Derivatives of 4-ene-3-one Steroids. Steroids, 78, 1152-1158. https://doi.org/10.1016/j.steroids.2013.08.004

[17] Patick, K. and Potts, K.E. (1998) Protease Inhibitors as Antiviral Agents. Clinical Microbiology Reviews, 11, 614-627. https://doi.org/10.1128/CMR.11.4.614

[18] Khan, H., Saeed, M., Muhammad, N., Gaffar, R., Gul, F. and Raziq, N. (2013) Lipoxygenase and Urease Inhibition of the Aerial Parts of the Polygonatum verticillatum. Toxicology and Industrial Health, 31, 758-763. https://doi.org/10.1177/0748233713483197

[19] Cannell, R.J.P., Kellam, S.J., Owsianka, A.M. and Walker, J.M. (1988) Results of a Large Scale Screen of Microalgae for the Production of Protease Inhibitors. Planta Medical, 54, 10-14. https://doi.org/10.1055/s-2006-962319 